UDC: 159.923

Oleksandr Sannikov,

PhD (Candidate of Psychological Sciences), senior researcher, associate professor, Department of Theory and Methodology of Applied Psychology, South Ukrainian National Pedagogical University named after K. D. Ushynsky, 4, Fontanska doroha Str., Odesa, Ukraine

\title{
INFORMATION SYSTEM OPERATOR: THE STRUCTURE AND COMPONENTS OF PERSONAL CHOICE
}

There has been considered the system organization of making a decision by an information system operator, the peculiarities of impact of operator's personal qualities on forming and making a choice. The paper presents the results of qualitative (correlative) and quantitative analysis (method of aces, profile method) and the description of a psychological aspect of operator's choice at two levels - subjective and environmental - formed by the set of interdependent components. The components of each level have been outlined; qualitative analysis of choice in the groups of dependent and self-dependent operators, the peculiarities of interconnection between decision-making properties have been described. The role of self-dependence in the system of choice properties has been shown.

Keywords: decision-making, choice subject, contradiction, indeterminacy, risk, components of a choice situation.

Problem statement. Data retrieval and information systems have become an integral part of business, particularly modern production management, banking sector and services sector. That kind of mass distribution minimizes the functions performed by an operator reducing them mainly to carrying out elementary algorithmic manipulations almost without any control over the state of software and hardware components of an information system. The implementation of this operation mode makes the role operator's qualification significant only in special situations [5]. The most common situations are emergency ones, which are characterized by high indeterminacy about their possible finishing and necessity for making a decision for their overcoming or balancing out negative consequences.

The review of special study results (T. Indina, 2010) has confirmed the existence of certain conditions for a situation when making a decision by a specialist becomes imperative: a) high level of indeterminacy and poor predictability of situation consequences; b) lack of information and strict time limitation for decision-making and its implementation; c) risk associated with situation development; d) stressful conditions of the implementation of operator's administrative functions; e) the necessity for generating non-standard solutions being aware of the responsibility for the consequences of a mistake made; $f$ ) enhanced responsibility for a decision made; $h$ ) heavy regulation of operator's activities by standing instructions, etc. [4, p. 337].

A reference point in considering decision-making as a necessity is a prompt analysis of the management situation that has arisen in the information system. From the standpoint of contemporary psychology, the emergence of a decision-making situation (as personal choice) should be considered in terms of contradiction of a subject of professional activity itself or as a contradiction between a choice subject (an operator) and the environment of administrative actions implementation (information system at work) [16]. In the first case, intrapersonal contradiction and its intensification source may affect negatively both operator's state and the indicators of work efficiency. In the second case, the situation of indeterminacy (incomplete determinacy or risk) may not only distort operator's idea of the information system state, but to destroy existing behaviour patterns in socio-technical environment.

\section{The role of a subjective factor}

The significance of the role of a subjective factor in "eliminating" indeterminacy is undoubtful and has certain relations with it. The analysis of indeterminacy situations causes shows that the structure and well-formedness of factors causing it vary in a broad range and extreme values characterize operator's individual characteristics: a) under conditions of absolute determinacy an operator makes simple decisions in elementary choice situations (situations of zero or "eliminated" indeterminacy); and b) under conditions of absolute indeterminacy an operator makes existential decisions in the situation of extreme choice (information object destruction succeeded by considerable financial losses, risk of destruction - operator's refusal to perform the duties).

One of the fruitful attempts to analyze the role of the subjective factor in decision-making was made by $\mathrm{Yu}$. Kozeletskiy [12]. Review of the content of the author's theoretical construct shows that it exists within currently available decision-making theories oriented at standard logical structure of decisions and, in fact, does not take into account the psychological mechanisms characterizing manifestations of a personality in choice situations. It allows us to consider this conception as belonging to the type of rational decision theories, which neglect personality's role in decision-making. Despite recognizing its real significance and complicated role in decisionmaking, when generalizing the results obtained, Yu. Kozeletskiy draws the following conclusion, “...a person capable of making good decisions should be characterized by certain personal traits, the latter having impact on the processes of solving the most difficult practical problems..." [12, p. 439]. Recognizing personality's regulative role in decision-making system makes Yu. Kozeletskiy's conception principally different from existing statis- 
tic theories of choice [12], conception of restricted rationality [23], rational behaviour under conditions of indeterminacy $[5 ; 6 ; 13]$. Under more complicated conditions of decision-making, impacts on intellectual and personal capacity intensify determining the necessity for introducing a limited number of personal variables (e.g. rationality, readiness for risk) into the theoretical construct (in addition to appealing to cognitive component, intellectual capacity, choice strategies) gradually approaching to real description of a personality in a choice situation $[9 ; 10]$.

These very conditions make it appropriate to consider the impact of operator's personal characteristics as decisionmaking predictors, which traditionally relate to components of "the subjective factor" in engineering psychology.

Study management and methodology

An empirical study has been carried out in order to test the suggested hypothesis. It involved 90 adult study participants (aged 24-45) who possessed formed skills and experience in operating information systems. In the course of the experiment (January-February, 2015) all the study participants were taking a retraining programme at South Ukrainian National Pedagogical University named after K. D. Ushynsky. The methods representing complementary indicators of making decisions by an operator were applied in the study. Psychodiagnostic complex included "Decision-making Scale", DMS (by T. Dembo S. Rubinstein, modified by A. Sannikov) [20], "Melbourne Decision-Making Questionnaire", MDMQ (by L. Mann, adaptation by T. Kornilova) [11], "DecisionMaking Questionnaire", DMQ (by Ye. Ilin) [3], "Personal Factors of Decision-Making", PFD-25 (T. Kornilova) [8].

\section{Results and their discussion}

Correlation relationships of the indicators of making decisions by an operator are represented in the Table 1 .

Table 1.

Significant correlation relationships of the indicators of qualities of a person making decisions $(n=69)$

\begin{tabular}{|c|c|c|c|c|c|c|c|c|}
\hline & \multicolumn{8}{|c|}{ Characteristics of decision-making scale } \\
\hline & $\mathrm{Ci}$ & Ad & $\mathrm{Sd}$ & Id & $\operatorname{Im}$ & Fs & Do & $\mathrm{Rp}$ \\
\hline $\mathrm{Ci}$ & & & $385 * *$ & & $-290^{*}$ & $431 * *$ & & \\
\hline $\mathrm{Ad}$ & & & & & $307 *$ & & & $400 * *$ \\
\hline $\mathrm{Sd}$ & $385^{* *}$ & & $\mathbf{T}$ & $-672 * *$ & & $251 *$ & & $333 * *$ \\
\hline Id & & & $-672 * *$ & & I & & $366^{* *}$ & $-397 * *$ \\
\hline $\operatorname{Im}$ & $-290 *$ & $307^{*}$ & 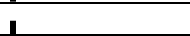 & & & & & $262^{*}$ \\
\hline Do & & & & $366^{* *}$ & & & & \\
\hline Fs & $431 * *$ & & $251^{*}$ & & + & & & \\
\hline $\mathrm{Rp}$ & & $400 * *$ & $333 * *$ & $-397 * *$ & $262 *$ & & & \\
\hline $\mathrm{Vi}$ & $269 *$ & -335 & & 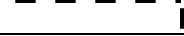 & $\mathbf{I}-380^{* *}$ & $328 * *$ & 1 & 2 \\
\hline $\mathrm{Ab}$ & & & $-381 * *$ & $499 * *$ & & & $\perp$ & \\
\hline $\mathrm{Pr}$ & & & $-435 * *$ & $426^{* *}$ & & $-246^{*}$ & & \\
\hline $\mathrm{Hv}$ & & & $-552 * *$ & $442 * *$ & & & & \\
\hline Ddm & $4 \overline{2} 8$ *** & & $489 * *$ & $-356 * *$ & & $9 *$ & 1 & - \\
\hline $\mathrm{Rg}$ & & & $-340 * *$ & $282 *$ & & & & \\
\hline Dmt & $--^{-338^{* *}}$ & & 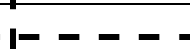 & ---1 & $433^{* *}$ & - - - $-291^{*}$ & & \\
\hline Rat & $-3 \overline{4} 5^{\text {类 }}$ & & & & & $291 *$ & & $-2-2$ \\
\hline $\mathrm{Rfr}$ & & & $422 * *$ & $-424 * *$ & & & & \\
\hline
\end{tabular}

Note: 1 ) here and elsewhere the symbols " 0 " and "." are omitted; 2 ) * correlation relationships at $\rho \leq 0.05$ level of significance; ** - correlation relationships at $\rho \leq 0.01$ level of significance; 3 ) reduction of the indicators of "Decision-making Scale" (DMS, A. Sannikov): Ci - circumstantiality, Ad adventurousness, Sd - self-dependence, Id - indecisiveness, Im - impulsivity, Do - dogmatism, Fs - far-sightedness, Rp - risk proneness; 4) reduction of the indicators of "Melbourne Decision-making Questionnaire" (MDMQ, L. Mann): Vi - vigilance, Ab - avoidance behaviour, $\mathrm{Pr}$ - procrastination, Hv - hypervigilance; 5) reduction of the indicators of "Decision-making Questionnaire" (DMQ, Ye. llin): Ddm - decisiveness in decision-making, $\mathrm{Rg}$ - rigidity, Dmtr - decision-making time rate; 6) reduction of the indicators of "Personal Factors of Decision-making" (PFD-25, T. Kornilova): Rat rationality, $\mathrm{Rfr}$ - readiness for risk.

The analysis of correlations between decision-making indicators has made it possible to discover the following common factors.

1. Correlation between the indicators of decisionmaking scale (DMS) shows the tendency to form consistent groups between the pairs of the scale: circumstantiality and adventurousness $(\mathrm{Ci}-\mathrm{Ad})$, self-dependence and indecisiveness $(\mathrm{Sd}-\mathrm{In})$, impulsivity and far-sightedness $(\mathrm{Im}-$ Fs), dogmatism - risk proneness (Do - Rp). One can assume that the distinguished pairs of the qualities tend to create continuums where completely developed operator's personal qualities form their extremes. It appears that selfdependence $(\boldsymbol{S} \boldsymbol{d})$ has the greatest number of significant relationships with other decision-making indicators, wherein positive relationships are revealed with the indi- cators of circumstantiality, Si $(0.385$, significance level $\rho \leq 0.01)$, far-sightedness, Fs $(0.251$, significance level $\rho \leq 0.05)$, risk proneness, $\operatorname{Rp}(0.333$, significance level $\rho \leq 0.01)$, decisiveness, $\operatorname{Ddm}(0.489$, significance level $\rho \leq 0.01)$ and readiness for risk, Rfr $(0.422$, significance level $\rho \leq 0.01)$. The group of indicators correlated positively with self-dependence $(\mathrm{Sd}+, \mathrm{Ci}+, \mathrm{Fs}+, \mathrm{Rp}+, \mathrm{Ddm}+$, $\mathrm{Rfr}+)$ represents a set of personality traits peculiar to a qualified operator: self-dependent, reasonable, farsighted, decisive specialist prone to and ready for risk.

II. The second group included the indicators that correlated negatively with self-dependence: indecisiveness, Id (- 0.672, significance level $\rho \leq 0.01$ ), avoidance behavior, Ab (- 0.381, significance level $\rho \leq 0.01$ ), procrastination, $\operatorname{Pr}(-0.435$, significance level $\rho \leq 0.01)$; hypervigilance, 
Hv (- 0.552, significance level $\rho \leq 0.01)$ and rigidity, $\mathrm{Rg}$ (- 0.340 , significance level $\rho \leq 0.01)$. Personality traits corresponding to the above mentioned indicators (Id-, Ab, Pr-, Hv-, Rg) characterize an unskilled operator: indecisive; prone to evade decision-making, to procrastinate making a choice; inconsistent in the hope to find a solution quickly; when making decisions he/she is inclined to unconsidered use of patterns developed before and not suitable for the situation.

Correlations between the indicators of the decisionmaking scale (DMS) forming a consistent group of positive relationships with indicators of other methods (MDMQ, DMQ and PFD-25) are of outstanding interest. It is reasonable to consider some tendencies of the discovered relationships of the indicators under study.

III. 1) there have been revealed regular positive relationships (significance level $\rho \leq 0.01$ ) of circumstantiality (Ci) with decisiveness, Ddm (0.428) and rationality in decision-making, Rat (0.345); 2) there have been revealed regular positive relationships of far-sightedness (Fs) with the indicators of vigilance, $\mathrm{Vi}(0.328$, significance level $\rho \leq 0.01)$, decisiveness, $\operatorname{Ddm}(0.309$, significance level $\rho \leq 0.05)$ and rationality in decision-making, Rat (0.291, significance level $\rho \leq 0.05)$; 3 ) there have been discovered positive relationships of risk proneness ( $\mathrm{Rp}$ ) with the indicators of adventurousness, Ad (0.400, significance level $\rho \leq 0.01)$, impulsivity, Im $(0.262$, significance level $\rho \leq 0.05)$ and readiness for risk, $\operatorname{Rfr}(0.393$, significance level $\rho \leq 0.01)$. The last group of indicators positively related to risk proneness $(\mathrm{Sd}+, \mathrm{Rp}+, \mathrm{Ad}+, \mathrm{Im}+, \mathrm{Rfr}+)$ represents personality traits of a qualified, self-dependent operator prone to adventurism: self-dependent, prone to adventurism and impulsive decisions, prone to and ready for risk. The content and structure of the relationships of the above mentioned characteristics of an operator prone to adventurism is understudied.

The revealed relations of the indicators make it possible to understand psychological origin of making decisions by an operator more deeply as well as to approach to the description of choice mechanisms in decisionmaking situations.

Orientation of the relations $(+,-)$ indicates operator's performance, reflects his/her proactive attitude in choosing a decision option, operator's ambition for eliminating contradictions arising in information system operation. These very factors facilitate the understanding of negative relations of self-dependence (circumstantiality, far-sightedness) with the indicators of indecisiveness, rigidity, avoidance behaviour and procrastination of choice: compensatory mechanism is activated, mechanism of replacing some decision-making properties with others in order to provide personality's psychological stability in a choice situation. Intolerance to indeterminacy, its rejection is balanced out by forming skills of knowing practical, prosocial strategies of solving problem situations, active mastering and use of coping strategy "vigilance" in making effective decisions. In this case, choice objectives and tasks are elaborated; all possible options suitable for the particular conditions are considered; the search for necessary additional and clarifying information is carried out; this information is assimilated ("without prejudice") into the conditions of the problem and choice success is evaluated before making final decision.

Operator's ambition for stability, especially in making decisions, is to a great extent responsible for negative relations of vigilance (Vi) with the indicators of adventurousness (Ad) and impulsivity ( $\mathrm{Im})$ in decision-making. Operator's personal feeling of indeterminacy induces him/her to be overcautious, which is perceived by others as tardiness. In order to overcome lack of self-confidence, indecisiveness and low tolerance one should repeatedly check the planned option implementation, the possibility to find an efficient solution, confirmation of the fact that the problem has been efficiently solved.

\section{Qualitative analysis of choice indicators}

Qualitative analysis of operator's personality traits facilitating decision-making shows that choice predictors can be a) the traits involved in the largest number of invariable correlation relationships with each other and b) the traits that make it possible to consider them as factors affecting operator's choice. Indicators of self-dependence and decisiveness in decision-making ( $\mathrm{Sd}, \mathrm{Ddm})$ meet the above mentioned requirements optimally. The structure of the independent variables, which are predictors of decisiveness, have been considered by us before [22]. The impact of self-dependence on the efficiency of operator's choice, the structure of its components and relations with other properties of decision-making should be investigated further.

Most scientists recognize the important role of selfdependence: in contemporary psychologists' works selfdependence is defined as a complex, integrated personality trait that consists of such components as independence - the ability to make and implement one's own decisions and achieve the goals by one's own efforts, without any supervising; initiative activity, i.e. readiness for implementing one's own undertaking, idea, intentions; ambition - the ability to predict results and to achieve goals; optimism - positive attitude, certainty about the possibility to achieve ultimate goal [2, p. 9]. M. Yegorova describes self-dependence more broadly, as a necessary parameter providing personality's readiness for responsible life. She considers self-dependence as a set of psychological functions and skills necessary for individual's performing complicated social actions. In her opinion, self-dependence consists of the following components: goal-setting, planning, decision-making, self-control (selfregulation), responsibility. Hence, self-dependence is represented by the author as a psychological basis of personality's conscious behaviour [1, p. 62]. In particular, self-dependence as well as the categories of "freedom" and "independence" are of great importance for selfunderstanding, self-realization and personality's selffulfillment (italics by A. Sannikov)[15, p. 370].

In order to specify operator's characteristics in a choice situation, two groups of study participants with 
high and low indicators of self-dependence have been formed. The first group involved the participants belonging to the $1^{\text {st }}$ quartile of sample distribution ( $\mathrm{Sd}-, \mathrm{n}=13$ people). The second group of participants belonged to the $4^{\text {th }}$ quartile ( $\mathrm{Sd}-, \mathrm{n}=19$ people). The pictures $1-3$ represent the graphs for mean values of both groups of the participants upon indicators of decisions making methods (DMS, MDMQ, DMQ). Let us consider the patterns of decision-making properties and personality characteristics of self-dependent and dependent operators. In order to make it easier to understand the peculiarities of interrelation between decision-making properties in the distinguished groups of operators, data of both groups is represented in the deviations from the mean line of the group's row. Such a form of data representation allows us to lose sight of and level out significant differences between the indicators of operator's choice, which are conditioned by the type of the system used (industrial process system, information system, financial system, etc.).

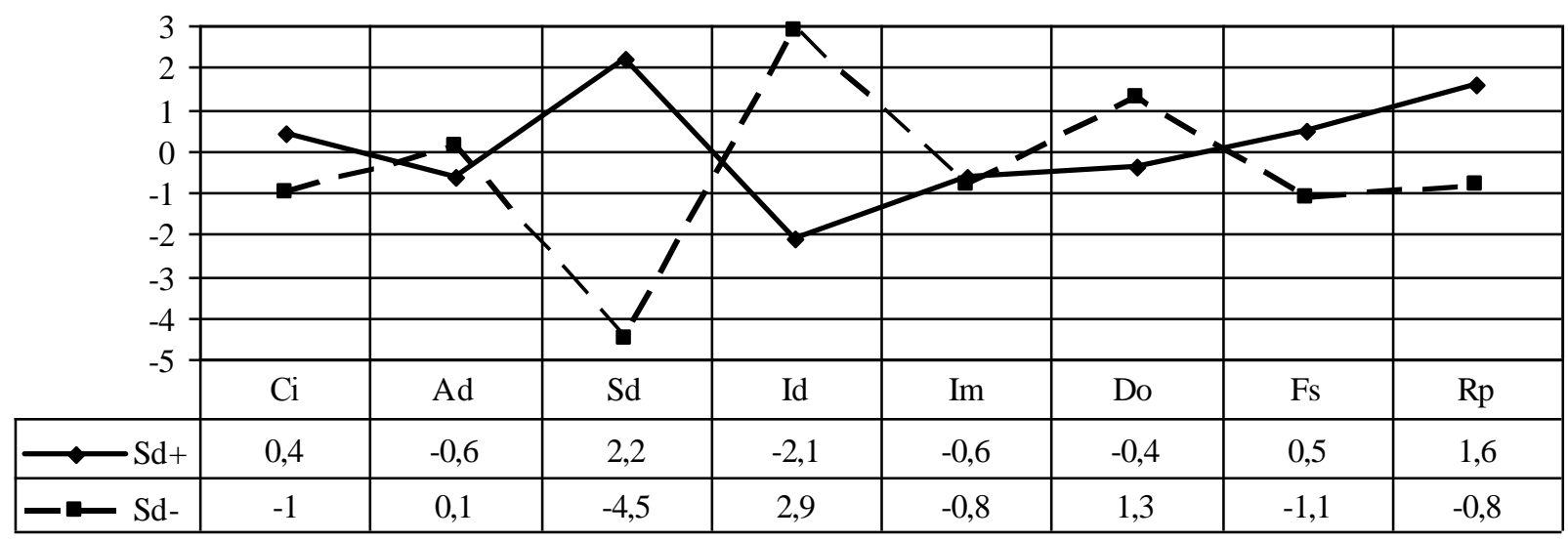

Picture 1. Patterns of the indicators of Decision-making Scale (DMS; Sannikov, 2014)

in the groups of operators with high ( $\mathrm{Sd}+)$ and low ( $\mathrm{Sa}$-) values of self-dependence indicators.

Note: Ci - circumstantiality, Ad - adventurousness in decision-making, Sd - self-dependence, Id - indecisiveness, Im - impulsivity, Do - dogmatism, Fs - far-sightedness, Rp - risk proneness.

The indicators of decision-making scale represented in the picture 1 demonstrate significant differences in choice properties of self-dependent and dependent operators. It should be noted that self-dependent operators are characterized by much more significant manifestation of circumstantiality $(\mathrm{Ci}+)$, self-dependence $(\mathrm{Sd}+)$, farsightedness (Fs+) and risk proneness $(\mathrm{Rp}+)$ whereas the indicators of indecisiveness (Id-) and dogmatism (Do-) are not manifested at all. As for operators with the low level of self-dependence ( $\mathrm{Sd}-$ ), the situation is reverse, except for the indicators of adventurousness (Ad) and impulsivity in decision-making (Im), which did not differ significantly in the compared groups. This fact may confirm the fact that information system operators typically demonstrate adventurousness and impulsiveness. Having gained professional experience, operators also acquire experience in predicting some changes in the characteristics of the system itself as well as in the system's aggregate units, which is recognized as adventurousness according to behavioural patterns. Impulsivity (Im) as a rapid and sometimes unconsidered way of managing the system is transformed into decision-making rapidity, time saving, which is permissible by the system itself for making management decisions. In case of making a mistake, an operator has an opportunity to correct it within the time provided by operating regulations.

Picture 2 represents the patterns of the indicators of Melbourne Decision-making Questionnaire (Kornilova,
2013) in the groups of operators in terms of their selfdependence level.

The comparison of the patterns represented in the picture 2 shows two opposite trends peculiar to most experienced and inexperienced operators. The group of self-dependent $(\mathrm{Sd}+)$ operators demonstrates high level of vigilance, the only personality trait that provides making rational decisions (according to the authors of the method) $(\mathrm{Vi}+)$. At the same time, it is observed that they more rarely demonstrate avoidance behaviour in making independent decisions, decisions postponement (which is associated with procrastination, $\mathrm{Pr}-$ ); hypervigilance (Hv), which is manifested in needless hesitating between two possible choice options, is demonstrated even more rarely than the above mentioned indicators. The specificity of the study was that there were no strict requirements as to the time of carrying it out. It was up to study participants to choose proper performance tempo; the task of test conductors was to monitor the scope of the work done. Opposite data has been obtained in the group of dependent operators (Sd-): the low level of vigilance (Vi-) with the high indicators of unconstructive strategies of decision-making ( $\mathrm{Ab}+, \mathrm{Pr}+$ and $\mathrm{Hv}+)$. Time for making proper decisions rises abruptly, "mirror effect" is reduced due to gaining experience in decision-making in variably complicated and time-limited choice situations. 


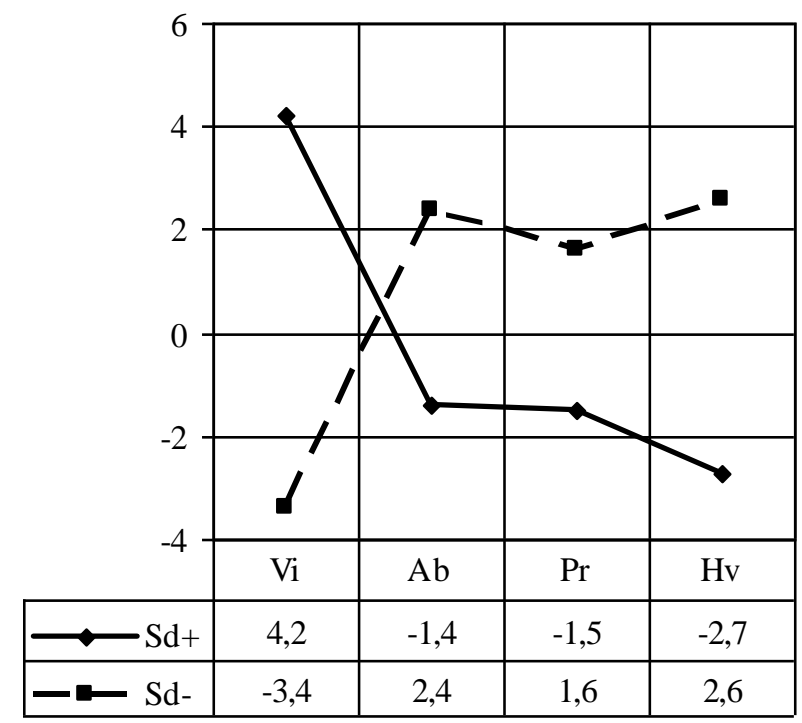

Picture 2. Patterns of decision-making indicators (MDMQ; Kornilova, 2013) in the groups of operators demonstrating high $(S d+)$ and low $(S d-)$ values of self-dependence indicators.

Note: $\mathrm{Vi}$ - vigilance, $\mathrm{Ab}$ - avoidance behaviour, $\mathrm{Pr}$ - procrastination, $\mathrm{Hv}$ - hypervigilance.

The analysis of decision-making indicators in terms of operator's self-dependence obtained by means of PFD-25 method (Kornilova, 2003) has shown the similarity of homonymous indicators. They were only different in terms of their expressiveness level, whereas self-dependent operators $(\mathrm{Sd}+)$ demonstrated more rationality in making decisions (Rat+) and higher level of readiness for risk ( $\mathrm{Rfr}+$ ), which confirms the common factors discovered before.

Picture 3 represents the patterns of personal factors of decision-making (Ilin, 2002) in the groups of operators with a certain level of self-dependence. The analysis of the patterns of decision-making factors confirms the fact that operator's self-dependence in decision-making is characterized by some peculiarities manifested in operator's com- mitment, search for decision option, his/her behaviour in general. The pattern of self-dependent operator demonstrates high values of all the indicators $(\mathrm{Ddm}+\mathrm{Rg}+$, Dmtr+) when determination (De+) for achieving a final positive result dominates sustainably. Rigidity performs a special function in decision-making - monitoring and checking if any choice option obtained is implemented. As for dependent operators, high level of rigidity $(\mathrm{Rg}+)$ is a limiting factor for them making it impossible to make final decisions (Ddm-, De-, Dmtr-). In terms of observable behaviour, dependent operators are similar to those ones who demonstrate procrastination $(\mathrm{Pr}+)$ both when looking for a choice option and thinking over its implementation.

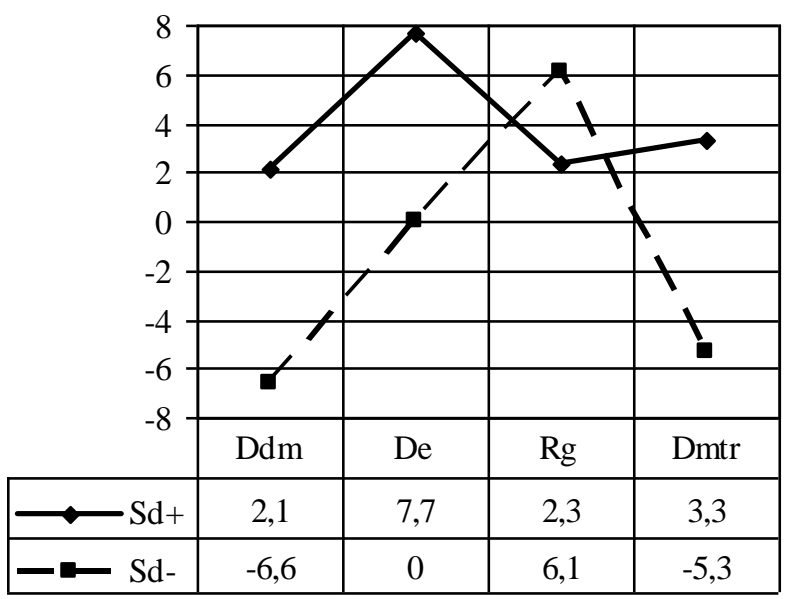

Picture 3. Patterns of the indicators of personal factors of decision-making (DMQ; Ilin, 2002) among the operators with high $(S d+)$ and low (Sd-) values of self-dependence indicators.

Note: Ddm - decisiveness in decision-making, De - determination in decision-making, Rg - rigidity, Dmtr - decision-making time rate. 


\section{The structure of choice situation}

Detailed consideration of the variety of operator's individually psychological characteristics and personality traits, development of conceptual choice model on their basis made it possible to specify the combination of decision-making predictors $[18 ; 19 ; 21 ; 22]$ and to distinguish the following components in a decision-making situation (performing the function of information system operation):

- choice subject (operator, the subject of professional activity);

- choice object (motive, act, action or the system of actions) exposed to the impact of the decision made by an operator as a choice subject;

- choice factors - work conditions, circumstances, reasons for contradiction (choice situation), which are actually choice source because of being perceived by an operator as causing anxiety (as "hazardous" in their extremes), reducing resistance of choice subject when operating the information system.

Correlation between the components of a choice situation may be represented as follows: source of contradictions $\rightarrow$ choice subject $\rightarrow$ choice factor(s) $\rightarrow$ decisionmaking $\rightarrow$ choice object(s) (Pic. 4 ).

Representing a choice situation as a synthesis of structural components may be reasonable only in case of making some allowances. There are a great number of situations perceived by an operator as hazardous, though, in fact, they are not. They are perceived this way due to some peculiarities of operator's emotional state (dominating emotional modality, neuropsychic anxiety). When a choice factor is determined by other operator's opinion, a number of variables unregulated by operator's consciousness in a decision-making situation increases considerably. The function of a choice factor may be performed even by other operator's emotional state (suggestion effect as well as contagion by the state of the subject inducing to make a choice are activated in sensitive people). Finally, decision-making is not just a psychic act (equal to the concept of "choice" in philosophic culture or psychotherapy), but it can act as psychic state in a decisionmaking situation (causing anxiety, mental block, avoidance behaviour, procrastination, aggression, etc.) or as an integral (synthetic) personal characteristics - readiness for choice, decision-making (immanently peculiar to operators of any systems - transport, industrial process system, financial, etc.).

The study of operator's readiness for decisionmaking reflects the most important crossing point of the problems of decision-making, subjective choice and psychology of a professional and, first of all, common factors of occupational selection, teaching and adaptation in information systems. For comprehensive accounting of factors determining decision-making parameters there is a need for accounting the formation of operator's volitional qualities, studying the locus of personal control, individual differences in making decisions depending on a personality and so on. Investigating common factors of person- al determination of decision-making is not only of academic interest.

In A. Karpova's opinion, "the important thing is that a personality is not just manifested in choice, it is being formed and developed though choice and taking responsibility related to choice, through activity, in which it is actualized. Therefore, determining subjective choice mechanisms as a major problem of decision-making psychology is the problem of personality development and socialization at the same time [7, p. 7]."

T. Kornilova shares this point of view relying on foreign and Russian investigations. In her opinion, a decision-making situation includes psychological readiness for choice, conation, readiness for risk and acts of consciousness (rationality), a set of certain actualized traits of a personality making decisions [10].

Interaction between the structural components of a choice

The content of operator's work and conditions of functions implementation in the information system make the distinguished structural components of a choice situation even more prominent and significant. Interaction of the considered components of a choice situation and conditions of operator's professional self-fulfillment introduces certain restrictions changing decision-making as a non-specific form of activity into decision-making activity with its specific features.

Any decision-making situation requiring operator's choice is analyzed by him/her in order to find out the reasons and circumstances (internal and external factors) that cause his/her mental discomfort (change, reduction of psychological stability) in case of system deviation from conditions of normal operation.

On the basis of such an analysis, an operator anticipates, forecasts further development of the situation, produces alternatives of its finishing (choice option) and assumed consequences. Among all the elaborated actions of information system operation, one chooses those ones which not only correspond to the professional work experience, but are necessary and sufficient for operator's achieving the objective planned. The decision made by an operator causes actions targeted at both operator's personality and his/her environment. The environment either experiences the consequences of the decision made or gets involved into its implementation. The variant of the right choice eliminates contradiction making the situation clear and determined for an operator fully or partly.

In case of making a mistake, knowing that the decision made is potentially wrong for this situation causes psychological instability of an operator's personality and, as a result, may be followed by substantial losses of the subject of activity and environment. Thus, a wrong decision and evaluation of its implementation in the information system are subjective characteristics: the same things may be perceived as wrong or right under different conditions of a regulatory situation when decision-making is required. It should be noted that a decision itself becomes the source of eliminating contradiction when an operator 
realizes the significance of choice factors, makes a decision and takes action - it is his/her action based on the decision made which determines the process of problem situation development: the problem can be either solved (eliminating contradiction, problem solving) or aggravate (results in refusing to make choice, searching for other choice option including such irreversible effects as abandoning work). Wrong decisions, misplaced choices, un- implemented incentives can lead to chain reaction, make a situation subjectively more difficult of even irreversible, change the conditions of information system operation or the choice subject (operator) him/herself.

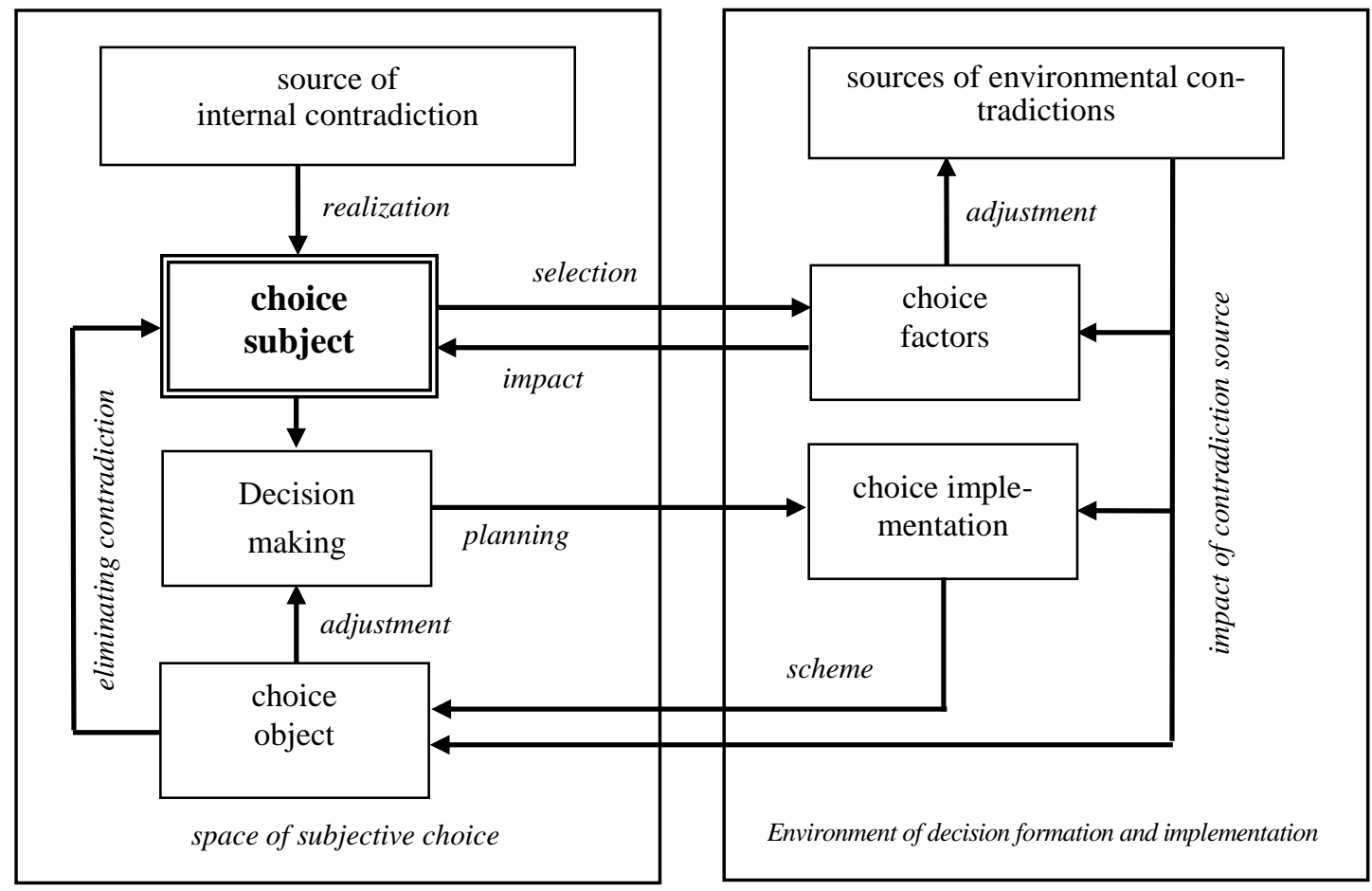

Picture 4. Structural components of an operational choice situation

\section{Levels of decision-making}

Obviously, the real structure of a situation (realized and accepted by an operator) has finite manifold of choice options. There may be distinguished at least three groups of decisions, which are equally possible in the process of information system operation:

- "external" decisions determined by the factors reflecting operational conditions;

- "social" decisions, social and psychological ones related to operator's work in the system of social relations (including in social networking sites, Internet users' sites);

- "internal" decisions, psychological by themselves determined by individually psychological, personal characteristics of an operator.

The latter have been of particular interest of scientists in recent years. The necessity for special study of a psychological aspect of making decisions by an operator is conditioned by the fact that it is formed, demonstrated and implemented at the following levels:

- information-perceptive level mediated by interaction of operator's cognitive characteristics [14, p. 385-404];

- subjective level conditioned by the impact of psychological structure of interrelated personality traits of an operator [17, p. 162-166];
- environmental level, which is determined by operator's actions targeted at implementation of the decision, which corresponds to the assumed objective of information system operation [8, p. 190-197]. Under these circumstances, it is important that implementation of the decision made by an operator is the arranged set of personality's actions aimed at changing the state of physical (information, virtual or object) environment and their evaluation - operator's evaluation of an active part of relevant self-fulfillment.

Properties of the information-perceptive level are considerably determined by the structure and complexity of display facilities included into the loop of information system operating by kind of hybrid intelligence [24]. The second, subjective level influencing and controlling the other levels of psychological system of making decisions by an operator is of particular interest and significance for understanding the complicated character of the outlined problem.

The subjective level of making decisions by an operator is formed by the system of interrelated components including social experience, cognitive, motivational and volitional components. Within a framework of these components, the influence of inner sources of a problem situation, the ambiguousness of a choice causing professional risks may arise, be eliminated or balanced out. 
Social experience as a component of decisionmaking is determined by the level of operator's wellformed knowledge, abilities, skills and habits. The experience includes variants of solving the problems of monitoring and control, frequently repeated decisions, skills of overcoming contradictions, the mature ability to solve difficult problems retained in operator's memory. The role of this experience is quite significant as long as decisions made in the situations of personal, existential choice, risk or indeterminacy should correspond to certain conditions. Stochastic nature of situations' further development, some elements of spontaneity, chance and stochastic behaviour of situations should be taken into account. It is the experience that makes an operator selfconfident; gives an opportunity to compensate for conditions of information gap and inability to evaluate the events unambiguously; makes it possible to overcome the limitations of time, physical and psychological resources of a choice subject at the moment of making a decision.

Cognitive component of a decision is associated with the assessment of the content and peculiarities of the situation arisen (situation of indeterminacy, risk or determinacy), with the review of available information and search for the information required for decision-making. Operator's ability to exceed the bounds of the existing situation in the process of its interpretation, to develop possible results and to find a decision option appropriate for the conditions of achieving the goal determines further transformation of the situation: towards reducing risk, eliminating indeterminacy, reducing its subjectiveness. Efficient decisions formation demonstrates operator's ability to calculate independently the possibility of achieving success or making a mistake when choosing one of the options. Thus, the level of determinacy (risk or indeterminacy) perceived by an operator in each situation of decision-making is a subjective characteristics, it is evaluated by means of individually psychological capabilities and limiting factors of an operator, his/her capability to distinguish, analyze and consider various factors influencing subjective choice itself as well as its result and possible consequences.

Motivational and volitional component is characterized by choice motives and operator's readiness for carrying out an act of will for making and implementing the decision aimed at overcoming risk or indeterminacy situation. Motivational constituent of this component provides operator's commitment and focus on achieving the objective of a decision; volitional constituent provides flexibility or stability of this activity depending on the fact if indeterminacy (risk) following the decision made is increasing or reducing, in this way performing the function of the subjective level regulator in general. Operator's activity in the situations of indeterminacy or risk is de-

\section{ЛИТЕРАТУРА}

1. Егорова М. А. Социально-психологическая готовность к самостоятельной жизни выпускников школы-интерната / Марина Алексеевна Егорова // Весник termined by his/her aiming at psychoemotional stability. If choice situation is understood as threatening for current self-fulfillment, possible change of efficiency of the decision made by an operator, aiming for success and avoidance of failure will become his/her major choice motives. A person concentrates his/her conation on the minimization of anticipated risk, in doing so, maintains psychological integrity of the system of personal intentions, ambitions implemented in choice and, therefore, provides his/her own psychoemotional stability. Motivation determines both self-fulfillment effectiveness and the nature of choice implemented in it. Choice development is connected with the identification of the reason for situation emergence, with its analysis and preparation of a rational decision and, first of all, with personal resource actualization, specification of the structure and level of manifestation of individually typological properties, skills and abilities which provide the achievement of the chosen objective [20, p. 195-196].

When an operator uses his/her personal resources and psychological potential irrationally, is not able to relate them to the stated objectives, which become difficult to accomplish, there may arise some risks related to professional stress, professional development crises, losing the meanings of substantive work and professional development violations.

\section{Conclusions}

1. The review of interrelations between individually psychological qualities of information system operator in choice situation makes it possible to determine the conditions of creating psychological system of decision-making and gives an opportunity to employ qualitative analysis for searching choice predictors.

2. Decision-making is system-organized at two interrelated levels - subjective and environmental. The subjective level represents a subsystem of mutually conditioned components - social experience, cognitive component, motivational and volitional component.

3. Motivational constituent provides operator's activity and commitment to achieving decision objectives; volitional component provides flexibility or stability of this activity changing choice indeterminacy and performing the function of the subjective level regulator. Social experience constituent makes major personality traits significant, appropriate for conditions of the situation of operator's choice predictors.

4. Self-dependence is the most informative predictor of decision-making in information system operation; it is an integrated individually psychological quality of a qualified operator, which consists of the number of properties: circumstantiality, far-sightedness, decisiveness, proneness to and readiness for risk. практической психологии образования. - 2007. - № 3. - C. 59-66. 
2. Гуріна 3. В. Психолого-педагогічні умови становлення самостійності у дітей раннього віку: Автореф. дис. ... канд. психол. наук / спец. 19.00.07 педагогічна та вікова психологія / Зоя Володимирівна Гуріна. - Київ, 2008. - 23 с.

3. Ильин Е. П. Мотивация и мотивы / Е. П. Ильин. - СПб. : Питер, 2002. - 512 с.

4. Индина Т. А. Регуляторно-личностные механизмы принятия решений в чрезвычайных ситуациях / Т. А. Индина // Известия РГПУ имени А. И. Герцена. - 2010. - № 124. - С. 336-347.

5. Канеман Д. Принятие решений в неопределенности: Правила и предубеждения / Д. Канеман, П. Словик, А. Тверски; пер.з англ. - Харьков : Изд-во «Гуманитарный Центр», 2005. - 632 с.

6. Карпов. А. В. Психология принятия решения в профессиональной деятельности: монография / А. В. Карпов. - Ярославль : Изд-во ЯрГУ, 1991. - 152 с. 11.

7. Карпов. А. В. Методологические основы психологии принятия решения / А. В. Карпов. - Ярославль : Изд-во ЯрГУ, 1999. - 232 с.

8. Корнилова Т. В. Психология риска и принятия решений: учебное пособие для вузов / Т. В. Корнилова. - М. : Аспект Пресс, 2003. - 286 с.

9. Корнилова Т. В. Методологические проблемы психологии принятия решений / Т. В. Корнилова // Психологический журнал. - 2005. - Т. 26. - № 1. - С. 7-17.

10. Корнилова Т. В. Саморегуляция и личностномотивационная регуляция принятия решений / Т. В. Корнилова // Субъект и личность в психологии саморегуляции / Под ред. В. И. Моросановой. - М. Ставрополь, 2007. - С. 181-194.

11. Корнилова Т.В. Мельбурнский опросник принятия решений: русскоязычная адаптация [Электронный ресурс] / Т. В. Корнилова // Психологические исследования. - 2013. - Т. 6, № 31. - С. 4. Доступ к реcypcy: http:// psystudy.ru.

12. Козелецкий Ю. Психологическая теория решений / Юзеф Козелецкий; Пер. с польск. Г. В. Минца и В. Н. Поруса. Послесловие Б. В. Бирюкова и О. К. Тихомирова. - М. : Прогресс, 1979. - 504 с.

13. Lipshitz, R., \& Strauss, O. Coping with uncertainty: a naturalistic decision-making analysis // Organizational Behaviour and Human Decision Processing. - Vol. 69. - 1997. - P. 149-163.

14. Обознов А. А. На пути построения системной модели психической регуляции операторской дея-

\section{REFERENCES}

1. Yegorova, M. A. (2007). Sotsialnopsikhologicheskaya gotovnost $\mathrm{k}$ samostoyatelnoy zhizni vypusknikov shkoly-internata [Social and psychological readiness for independent living of boarding school graduates]. Vestnik prakticheskoy psikhologii obrazovaniya Bulletin of practical educational psychology. (Vol. 3). (pp. 59-66) [in Russian]. тельности / А. А. Обознов // Идея системности в современной психологии / Под ред. В. А. Барабанщикова. - М. : Изд-во «Институт психологии РАН», 2005. $496 \mathrm{c}$.

15. Помиткіна Л. В. Особистісні детермінанти прийняття студентами стратегічних життєвих рішень / Любовь Витальевна Помиткіна // Проблеми загальної та педагогічної психології: Збірник наукових праць Інституту психології імені Г. С. Костюка НАПНУ. T. XIV. - Ч. 6. - 2012. - С. 366-374.

16. Санников А. И. Психологические характеристики взаимодействия: анализ содержания и уточнение понятий / А.И. Санников // Вісник Одеського національного університету. Том 15. Вип. 11. Ч. 1. Психологія. - Одеса: Астропринт, 2010. - С. 414-422.

17. Санников А. И. Личностные факторы принятия решений / А. И. Санников // Наука і освіта. Спецвипуск «Психологія особистості: теорія, досвід, практика». - 2012. - №6/CVVII. - С. 162-166.

18. Санников А. И. Личностные аспекты принятия решений профессионалом / А. И. Санников // Наука i освіта. Спецвипуск «Психологія особистості: теорія, досвід, практика». - 2013 - №7/CXVII. - С. 295-303.

19. Sannikov A. I. Activities and decision-making: a comparative analysis // Materials of the VII international research and practice conference «European Science and Technology». - Vol. II, Munich, April 23-24th, 2014. Munich - Germany. - 2014. - P. 364-368.

20. Санников А. И. Мотивация и побуждение в исследованиях принятия решений / А. И. Санников // Наука і освіта. - 2014. № 11/CXXVIII. - C. 190-197.

21. Sannikov A. I. On the construction of meaningful decision-making model // Proceedings of the 1st European Conference on Education and Applied Psychology. «East West» Association for Advanced Studies and Higher Education GmbH. Vienna. - 2014. - P. 107-112.

22. Санников А. И. Личностные предикторы принятия жизненных решений / А. И. Санников // Наука i освіта. - 2015. - № 10 / CXXXIX. - C. 217-230.

23. Simon H. A. Theory of Decision-making in economics and statistical // Psychological Bulletin. - Vol. 68. - 1967. P. 29-46.

24. Венда В. Ф. Системы гибридного интеллекта: Эволюция, психология, информатика / В. Ф. Венда. М. : Машиностроение, 1990. - 448 с.

2. Hurina, Z. V. (2008). Psykholoho-pedahohichni umovy stanovlennia samostiinosti u ditei rannoho viku [Psychological and pedagogical conditions for forming independence in young children]. Extended abstract of candidate's thesis. Kyiv [in Ukrainian].

3. Ilin, Ye. P. (2002). Motivatsiya i motivy [Motivation and motives]. St. Petersburg: Piter [in Russian]. 
4. Indina, T. A. (2010). Regulyatorno-lichnostnyye mekhanizmy prinyatiya resheniy $\mathrm{v}$ chrezvychaynykh situatsiyakh [Regulatory and personal mechanisms of decision-making in emergency situations]. Izvestiya RGPU imeni A. I. GertsenaHerzen University Journal of Humanities and Sciences «Izvestia». (Vol. 124). (pp. 336-347) [in Russian].

5. Kaneman, D., Slovik, P. \& Tverski, A. (2005). Prinyatiye resheniy $\mathrm{v}$ neopredelennosti: Pravila i predubezhdeniya [Decision-making in uncertainty: Regulations and prejudice]. Kharkov: Izdatelstvo «Gumanitarnyy Tsentr» [in Russian].

6. Karpov, A. V. (1991). Psikhologiya prinyatiya resheniya $v$ professionalnoy deyatelnosti: monografiya. [The psychology of decision-making in professional work: monograph]. Yaroslavl: Izdatelstvo YarGU [in Russian].

7. Karpov, A. V. (1999). Metodologicheskie osnovy psikhologii prinyatiya resheniya [Methodological bases of psychology of decision-making]. Yaroslavl: Izdatelstvo YarGU [in Russian].

8. Kornilova, T. V. (2003). Psikhologiya riska i prinyatiya resheniy [Psychology of risk and decision-making]. Moscow: Aspect Press [in Russian].

9. Kornilova, T. V. (2005). Metodologicheskie problemy psikhologii prinyatiya resheniy [Methodological problems of psychology of decision-making]. Psikhologicheskiy zhurnal Psychological journal, 1, 7-17. (Vol. 26) [in Russian].

10. Kornilova, T. V. (2007). Samoregulyatsiya i lichnostno-motivatsionnaya regulyatsiya prinyatiya resheniy [Self-control and personally motivational regulation of decision-making]. Subyekt i lichnost v psikhologii samoregulyatsii - Subject and personality in psychology of selffulfillment. Morosanova V. I. (Ed.). (pp. 181-194). Moscow - Stavropol [in Russian].

11. Kornilova, T. V. (2013). Melburnskiy oprosnik prinyatiya resheniy: russkoyazychnaya adaptatsiya [Melbourne decision-making questionnaire: the Russianlanguage adaptation]. Psikhologicheskie issledovaniya Psychological research. Vol. 6, 31, p. 4. Retrieved from: http://psystudy.ru [in Russian].

12. Kozeletskiy, Yu. (1979). Psikhologicheskaya teoriya resheniy [Psychological decision theory]. (G. V. Mintsa i V. N. Porusa, Trans.). Moscow: Progress [in Russian].

13. Lipshitz, R., \& Strauss, O. (1997). Coping with uncertainty: a naturalistic decision-making analysis. Organizational Behaviour and Human Decision Processing. (Vol. 69). (pp. 149-163) [in English].

14. Oboznov, A. A. (2005). Na puti postroeniya sistemnoy modeli psikhicheskoy regulyatsii operatorskoy deyatelnosti [Towards building a system model of mental regulation of operator's activity]. Ideya sistemnosti $v$ sovremennoy pskihologii - Idea of systemacity in modern psychology. V. A. Barabanschikov (Ed.). (pp. 386-404).
Moscow: Publishing House of the «Institute of Psychology, Academy of Sciences» [in Russian].

15. Pomytkina, L. V. (2012). Osobystisni determinanty pryiniattia studentamy stratehichnykh zhyttievykh rishen [Personality determinants of making important strategic decision by students]. Problemy zahalnoi ta pedahohichnoi psykholohii: Zbirnyk naukovykh prats Instytutu psykholohii imeni H. S. Kostiuka NAPNU - Problems of General and Educational Psychology: Proceedings of the Institute of Psychology named after H. S. Kostiuk of the NAPS. (Vols. 14, Pt. 6). (pp. 366-374) [in Ukrainian].

16. Sannikov, A. I. (2010). Psikhologicheskie kharakteristiki vzaimodeystviya: analiz soderzhaniya i utochnenie ponyatiy [Psychological characteristics of interaction: content analysis and specification of concepts]. Visnyk Odeskoho natsionalnoho universytetu - Bulletin of Odessa National University, 11, 414-422. (Vols. 15). Odesa: Astroprint [in Russian].

17. Sannikov, A. I. (2012). Lichnostnye faktory prinyatiya resheniy [Personal factors of decision-making]. Nauka $i$ osvita - Science and education, 6, 162-166 [in Russian].

18. Sannikov, A. I. (2013). Lichnostnye aspekty prinyatiya resheniy professionalom [Personal aspects of making decisions by a professional]. Nauka i osvita - Science and education, 7, 295-303 [in Russian].

19. Sannikov, A. I. (2014a). Activities and decisionmaking: a comparative analysis. Proceedings of the VII international research and practice conference "European Science and Technology». (Vols. II). Munich, April 23 th -24 th, 2014. (pp. 364-368) [in English].

20. Sannikov, A. I. (2014b). Motivatsiya i pobuzhdenie $\mathrm{v}$ issledovaniyakh prinyatiya resheniy [Motivation and incentives in research on decision-making]. Nauka i osvita - Science and education, 11, 190-197 [in Russian].

21. Sannikov, A. I. (2014c). On the construction of meaningful decision-making model. Proceedings of the 1st European Conference on Education and Applied Psychology. «East West» Association for Advanced Studies and Higher Education GmbH. Vienna. (pp. 107-112) [in English].

22. Sannikov, A. I. (2015). Lichnostnye prediktory prinyatiya zhiznennykh resheniy [Personality predictors of making important decisions]. Nauka i osvita - Science and education, 10, 217-230 [in Russian].

23. Simon, H. A. (1967). Theory of Decision-making in Economics and Statistics. Psychological Bulletin, 68, 29-46 [in English].

24. Venda, V. F. (1990). Sistemy gibridnogo intellekta: Evolyutsiya, psikhologiya, informatika [Hybrid intelligence systems: evolution, psychology, computer science]. Moscow: Mechanical engineering [in Russian]. 
Александр Ильич Санников,

кандидат психологических наук, стариий научный сотрудник, доцент кафедры теории и методики практической психологии, Южноукраинский национальный педагогический университет имени К. Д. Уиинского, ул. Фонтанская Дорога, 4, г. Одесса, Украина

\section{ОПЕРАТОР ИНФОРМАЦИОННОЙ СИСТЕМЫ: \\ СТРУКТУРА И КОМПОНЕНТЫ ВЫБОРА ЛИЧНОСТИ}

Рассматривается системная организация принятия решения оператором информационной системы, особенности влияния свойств личности оператора на формирование и реализацию выбора. Определены роль и место принятия решений в структуре операторской деятельности. Представлены результаты количественного (корреляционного) и качественного анализа (метод асов и профилей) ведущих профессионально важных качеств оператора информационной системы. Даны основные характеристики и описание шкал принятия решений, представлены результаты анализа устойчивых групп, образованных парами шкал: обстоятельность и авантюрность, самостоятельность и нерешительность, импульсивность и дальновидность, догматичность и склонность к риску. Описаны результаты качественного анализа выбора в группах самостоятельных и несамостоятельных операторов, особенности взаимосвязи выделенных свойств принятия решений. Показана роль самостоятельности в системе свойств личности, принимающей решение, а также выделены ее составляющие. Рассмотрена структура психологической системы принятия решений, реализованная на двух уровнях - субъектном и средовом, образованных комплексом обусловливающих друг друга компонентов. Выделены компоненты каждого из уровней, представлен содержательный анализ реализуемых функций. Описаны характеристики и роль социального опыта как компонента системы принятия решения. Развернута регулятивная функция мотивационно-волевого компонента системы, особенности использования оператором личностных ресурсов в ситуации риска.

Ключевые слова: принятие решения, субъект выбора, противоречие, неопределенность, риск, компоненты ситуации выбора.

Олександр Ілліч Санніков, кандидат психологічних наук, стариий науковий співробітник, дочент кафедри теорії і методики практичної психології, Південноукраїнський національний педагогічний університет імені К. Д. Уиинського, вул. Фонтанська Дорога, 4, м. Одеса, Украӥна

\section{ОПЕРАТОР ІНФОРМАЦЙНОЇ СИСТЕМИ: СТРУКТУРА І КОМПОНЕНТИ ВИБОРУ ОСОБИСТОСТІ}

Розглядається системна організація прийняття рішення оператором інформаційної системи, особливості впливу властивостей особистості оператора на формування і реалізацію вибору. Визначено роль і місце прийняття рішень у структурі операторської діяльності. Представлені результати кількісного (кореляційного) і якісного аналізу (метод асів, метод профілів) провідних професійно важливих якостей оператора інформаційної системи. Представлено основні характеристики і опис шкал прийняття рішень, а також результати аналізу стійких груп, утворених парами шкал: грунтовність і авантюрність, самостійність і нерішучість, імпульсивність і далекоглядність, догматичність і схильність до ризику. Описано результати якісного аналізу вибору в групах самостійних і несамостійних операторів, особливості взаємозв'язку виділених властивостей прийняття рішень. Показано роль самостійності в системі властивостей особистості, яка приймає рішення, виділено їі складові в системі властивостей особистості. Розглянуто структуру психологічної системи прийняття рішень, яка реалізована на двох рівнях - суб'єктному і середовищному, утворених комплексом компонентів, які обумовлюють один одного. Виділено компоненти кожного з рівнів, представлено змістовний аналіз реалізованих функцій. Описано характеристики і роль соціального досвіду як компонента системи прийняття рішення. Розкрито зміст регулятивної функції мотиваційно-вольового компонента системи, особливості використання оператором особистісних ресурсів в ситуації ризику.

Ключові слова: прийняття рішення, суб'єкт вибору, протиріччя, невизначеність, ризик, компоненти ситуації вибору.

Подано до редакиії 28.07.2016

Рецензент: д. психол. н., проф. В. В. Плохіх 